\title{
THE COMPARATIVE ANALYSIS BETWEEN WINTER SPORTS CENTRE POPOVA SAPKA AND SPORTS CENTRE BREZOVICA
}

DOI: http://dx.doi.org/10.18509/GBP.2017.24

UDC: 338.48-52:796.9(234.42)

\section{Zejnedije Ademi}

Institute of Geography, Faculty of Natural Sciences and Mathematics, University of Tetovo, Macedonia

\begin{abstract}
Shar Mountain with a favorable geographical position, with a geological and tectonic composition, with relief forms, climatic characteristics, rich hydrography, flora and fauna, anthropological features, demographical quality of the population, makes it possible the development of the winter sports tourism.

Researching subjects are the two winter sports centers, PopovaSapka, a well-known winter sports center in the Republic of Macedonia as well as Brezovica, also a well-known touristic center in Republic of Kosovo.

From the results of the comparative analysis between the two touristic centres, I came to the conclusion that in Shar Mountain, until now as the sole winter touristic centers are Popova Sapka and Brezovica, the same are developed enough for the development of the winter tourism, they fulfill the primary criteria starting from the skiing terrains, ski lifts, telephers, up to the accommodation capacity, with which they fulfill the hitherto touristic requirements and give hope for the rise of the touristic offer in the existing localities, with the widening of the sports skiing terrains and the advancement of the touristic infrastructure.

The methods with which the research has been elaborated are various, the use of the analysis method in the research of the natural and geographical characteristics indicates the recognition of the all geo-components in Shar Mountain.

The method of valorisation shows the verification of certain features. The winter sports centre Popova Sapka with the small houses, skiing terrains, ski lifts, telphers and accommodation capacities. The winter touristic centre, Brezovica with its small houses, skiing terrains, ski lifts, telphers and accommodation capacities, the inclusion of the centre as part of the national park "Shari" in Kosovo.

From the knowledge and the achieved results for the natural characteristics that have influence here, we can conclude that the Shar Mountain as the biggest mountain range in the Republic of Macedonia has convenient conditions for the development of the winter tourism in the both above mentioned localities.

My suggestion is to improve the image of these centers in the foreign markets because they are not promoted enough, as it is the promotion in web pages.

The telephers that go to Popova Sapka should start functioning as soon as possible, to initiate and organize entertaining and sports activities with which the touristic offer will rise, the accommodation buildings need to be repaired and to start the building of new hotels with contemporary conditions, the use of European funds and above all to neglect the political influences in the development of touristic centres.
\end{abstract}

Keywords: Shar Mountain, Popova Sapka, Brezovica, skiing infrastructure, accommodation capacities, the comparative analysis between both centres. 


\section{POPOVA SHAPKA, A WELL-KNOWN CENTER FOR WINTER SPORTS IN MACEDONIA}

Popova Shapka, as a tourist center for winter sports, has got a very suitable geographical and communicative position, it's located near Skopje, the capital of Republic Macedonia and near other two cities, Tetovo and Gostivar.

The communicative connection of Popova Shapka with the nearest city, Tetova, mainly is done by a paved road which goes through some mountain villages: Gajre, Shipkovica and Lisec.

Another communicative connection does exist even by cable car, which is $7 \mathrm{~km}$ long, but unfortunately the same has not been working for a decade now.

Popova Shapka and it's sorrounding area is abundant with an enormous number of natural resources, areas that are considered very appropriate for sport fields, accommodation capacities and some other infrastructural facilities. There, though a very tiny area, we can find lots of geomorphological, hydrologic and biogeograpic, and also some antropogenic motives. The relief forms have some interesteing and attractive characteristics such as are of Popova Shapka, Jellaku, Mount Bakerdan ( 2704), Turçin (2702) and the summit of Tito (2748). [1]

Waters, besides their vital role, have a very important role for development of tourism. The Mount Shar dhe and tourist place Popova Shapka, are very abundant in springs and rivers. Springs in Jelak provide all accomodation facilites and villas in Popova Shapka. This represents a factor very useful in this tourist location and beyond that.

In tourist location Popova Shapka the first accommodation facility was builtin 1934, the hotel "Popova Sapka" totally with 26 rooms and 220 beds. [2]

While, accommodation facilities that are active these days may be find in the following: The hotel "Popova Sapka" of ***star category. It is $1737 \mathrm{~m}$ above sea level, very close to skiing terrains. It is in possession of 58 rooms, 2 appratmants, food hall, TV saloon, disco, parking.

The hotel "Sllavia" is a hotel of ***star category. It is located $1780 \mathrm{~m}$ above sea level. Is in possession of 52 rooms, 6 apartmants, food hall, cafeteria, closed swimming pool, fitness facility, pools, parking.

The hotel "Arena" is of *** star category, located $1972 \mathrm{~m}$ above sea level. Is in possession of 25 rooms, 3 apratments, TV saloon, disco and parking.

The hotel "Konaku i Nolit" is of **** star category, possesses 11 rooms and 5 apratments with up-to-date conditions.

The hotel "Snow Patrol Lodge" is of ****star category, possesses 15 rooms, restaurant, food hall, cafiteria, etc.

The hotel "Bora" is of *** star category, posseses 10 rooms, food hall, etc.

The hotel "Skardus" is of **** star category. Posseses 35 rooms, night bar, restaurant, room for skies, laundery, conference room, SPA center within which there are two saunas, Jacuzzi, dy swimming pools, turkish baths dhe fitness, parking.

During winter season, even these hotels start working: "Baçilo", "Casa Leone", "Konak" etc.

The winter sport center Popova Shapka, as we mentioned earlier, posseses suitable terrains for skiing, which are interlinked with cable cars, ski-lifts, a center which in Republic of Macedonia i considered as a popullar tourist center.

A convincing indicator is the fact that in Popova Shapka since 1947 has been organized 'Kupa e Sharit', a competition that welcomes not only domestic skiers, but also 
competitiors from neighboring states and European states: Austria, Italy, Germany, etc. This ski center posseses totally 5 ski-lifts: Teteks 1 , Teteks 2 , Aerodrom, GE, Jellak.

The general capacity of skiers amouts to 8000 skiers per hour. Terrains for skiing in Popova Shapka are in south position and south-east position, the paths are classified in three categories: easy paths for skiing, intermediate paths for skiing, and difficult paths for skiing. Almost all paths start on the sea level of 2400 meters and end somewhere in 1400 meters, with a slope of $6.67 \%$ to $32,6 \%$. [3]

In this winter center it is planned to be built totally 13 ski-lifts dhe 3 cable cars with length of $16900 \mathrm{~m}$, which, according to the plan, should carry 13770 skiers per hour, so attention should be paid to adventure sports like Snowboard.

In Popova Shapka besides hotel facilities, of huge importance for accommodation of tourists are villas which are to be found near hotels in the east, scattered in cascade-like way on sea level from 1750 to $1900 \mathrm{~m}$. Because of the attractiveness of this location, the number of objects in this place has increased very fast, an increase that causes problems with municipality services. Municipality of Tetova is compiling an urban plan which predicts building of 600 new villa, some hotels, parkings and sport terrains. [4]

\section{Brezovica, well-know center for winter sports in Kosovo}

Bresovica, a winter tourist center, is $12 \mathrm{~km}$ far from the village of the same name in Municipality of Shtërpca. It has an area of 2500 hektar, on the sea level of 1718 to 2522 m. [5]

Based on the features of geologic and geomorphologic composition, characteristics are similar with those of Popova Shapka, only because of the fact that both centers are part of the mountain massive, Shari. In the tourist locality, Brezovica, the first object facilities has been built since 1960 such as: " Shtëpia e Gurit', 'Baqilla ', 'Shtëpia e Stojkut'.

Hotel faciliies that are in function lately in the tourist center are:

The hotel "Breza", is of ***star category. It posseses 30 rooms and 70 beds, food hall, parking.

The hotel "Narciz", is of **** star category, posseses 115 rooms and totally 320 beds, food hall, cafe bar, parking, etc.

The hotel "Molika" is of ***star category, posseses 1320 rooms and 300 beds.

The hotel "Pine" is of **** star category, posseses 6 rooms, restaurant, cafe-bar, etc.

The hotel "Centar" which posseses only 12 rooms and 30 beds.

Besides above-mentioned facilities, there are some hotel functioning these days like: the hotels " Sport Tours", " Braca", "Fox", "Tina", "Woodland" etc.

Lately in the ski center Bresovica the number of tourist is descending and investments in this center are also in decline. Hotels, cable cars and other objects do not function on full scale. In addition to hotel facilities, tourists have got the opportunity to use villas that are found in this tourist center, near the hotel Molika, whose number amounts to 270, but new objects are being built in continuity.

But, the building of unplanned villas according to urban plan is taking off, a process that copes with troubles like lack of drinkable water, sewage system, garbage, etc..

The ski center Brezovica is in possession of terrains very appropriate for skiing. There are 8 paths for skiing: Karaula, Piriberg Beravac, the Neck of Avalanche, Baçila, Munika, Greek Medow, the Red Karpa. The length of paths for skiing is $40 \mathrm{~km}$ with $38 \%$ avarage curve. Almost all paths start on the sea level of $2300 \mathrm{~m}$ and end at $1700 \mathrm{~m}$. [6]

Despite this solid number of paths and cable cars, there is a stagnation of tourist which consequently deteriorates their maintainance. The main purpose for better image of this 
winter center is: to provide transportation of skiers to the point they descend from, activation of cable cars which are out of order, building of new ski-lifts and cable cars in the existing center after Brezovica.

\section{CONCLUSION}

Mount Shar with very suitable geographical position, suitable climate for the development of winter-sport tourism, relief forms and suitable terrains for skiing paths has contributed to the development of Popova Shapka and Bresovica as well-known centers for winter sports, the first one in Macedonia and the second one in the Republic of Kosovo.

Both centers posseses the necessary infrastructure for the development of winter-sport tourism, in fact skiing, although both of them face the same problems among which are non-investment in existing infrastructure, the lack of snowboard paths.

Accommodation facility like hotels and villas so far has managed to accommodate all tourists who have aimd these to tourist centers. Here it is very important to say that in both of these centers the are no objects of high category that would meet the needs of foreign tourists.

The common objective of these two centers is extension and development of existing infrastructure not breaching the contemporary criteria of the cross-roading DragashTetovo.

Both centers should apply for international funds with common projects of Kosovo and Macedonia about the interborder zone of Mount Shar, and also they should map a common project for creating better conditions for interborder circulation for better use of capacities of Brezovca and Popova Shapka at the same time.

\section{REFERENCES}

[1] Stefanovski,Zh.(1981), Shar Planina. Tetovo.

[2] Štetić S. \& Šimičević D, "Menadžment turističke destinacije” Beograd, 2008.

[3] Municipality of Tetovo, Sector of urbanism, Tetovo.

[4] Komuna e Tetovës.(2002). Profil i Komunës Tetovës. Zyra LER, Tetovë.

[5] Panov, N.(1994). Kompleksni proucuvanja na rezidencijalniot turizam vo Republika Makedonija, Skopje.

[6] Plani hapësinor,(2013), Parku kombëtar "Sharri”, Instituti për Planifikim Hapësinor, Ministria e Mjedisit dhe Planifikimit hapësinor, Republika e Kosovës, Prishtinë.

[7] http://www.brezovica-ski.com

[8] www.popovasapka.mk 